\title{
A SUMMARY OF \\ MINERAL PRODUCTION IN IOWA \\ 1895-1938 \\ by
}

H. GARLAND HERSHEY 



\section{TABLE OF CONTENTS}

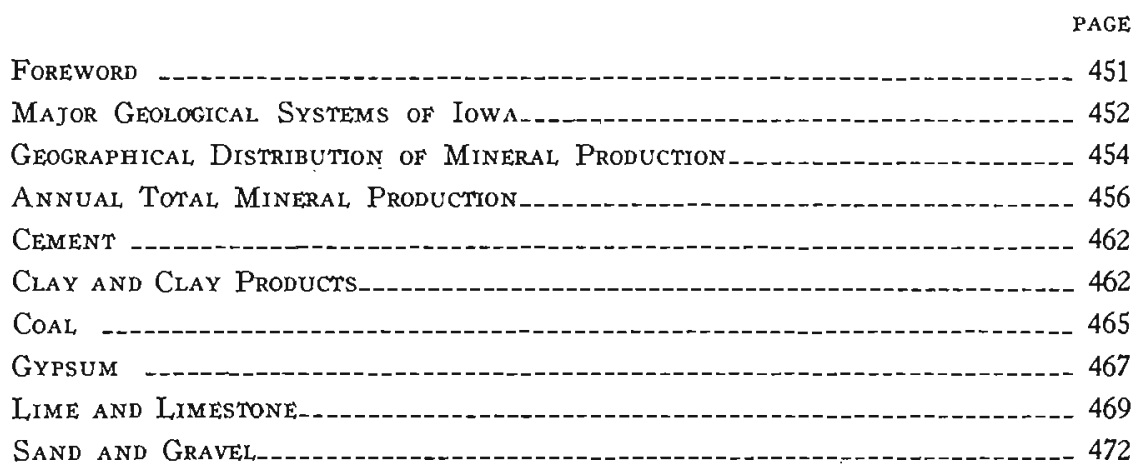

\section{LIST OF ILLUSTRATIONS}

PLATE

PAGE

I. Fig. A-Geographic distribution of lime and limestone and cement producers -

Fig. B - Geographic distribution of coal producers

Fig. C - Geographic distribution of gypsum, clay and clay products producers -..-- 455

Fig. D - Geological map-_-_-_-_-_-_-_-_-_-_-_._-_-_-_-_-_-_ 455

II. Circle diagram showing total mineral production in Iowa 1895-1938----- 457

III. Columnar diagram showing total mineral production in Iowa 1895-1938_- 459

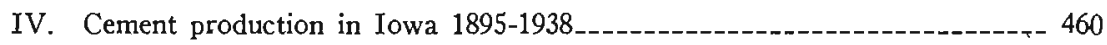

V. Clay production in Iowa 1895-1938

VI. Coal production in Iowa 1895-1938

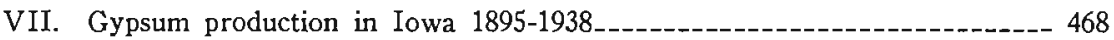

VIII. Lime and limestone production in Iowa 1895-1938_._...........-. 470

IX. Sand and gravel production in Iowa 1895-1938_._-_...............-...- 473 



\section{A SUMMARY OF MINERAL PRODUCTION IN IOWA 1895-1938}

\section{Foreword}

The purpose of this report is. to present in condensed form the trends in the development of the minerals industries in Iowa from 1895 to 1938. The Iowa Geological Survey and the United States Bureau of Mines publish reports on annual mineral production which provide detailed economic reviews for individual years. It is not their purpose, however, to summarize statistics of all preceding years and it is difficult, therefore, to obtain a composite picture of the development of production quantities and values over long periods. A summary of mineral productions in Iowa is needed for the 43-year period 18951938 and the following report was assembled to fulfill that need.

In preparing the report the aim was to outline only the outstanding features of the development of production of leading individual minerals and of the minerals industries as a whole. It was felt that this could be accomplished best by the use of diagrams and tables. These make up a large portion of the report and the discussion is intentionally short.

The leading mineral commodities produced in the state during the period were coal, clay and clay products, cement, gypsum, lime and limestone, and sand and gravel. Normally they made up more than 99 per cent of the total annual state mineral production. Of less importance were lead and zinc, sandstone, iron, mineral waters, mineral paint, sand lime brick, potash, natural gas and peat. Summaries of only the leading products are presented although the total yearly productions include the minor products.

Certain policies followed in the annual reports are also followed here. The production of sandstone, which is normally small, is included with lime and limestone. Raw clay is excluded from total yearly productions but is included in the figures for clay and clay products. The data presented for cement are based on the quantity and value of cement shipped from the mills. 
The figures for quantity and value of production appearing in the tables were taken almost entirely from mineral reports of the Iowa Geological Survey, although a few were obtained from publications of the United States Bureau of Mines and the United States Geological Survey. These data were collected originally under a cooperative agreement between the State Survey and the two Federal agencies mentioned, except the data for clay, whch were furnished by the United States Bureau of the Census after collection by that agency without state cooperation.

The published reports of the various agencies do not always agree because of differences in the methods of interpreting and presenting data submitted by producers. Furthermore, in many cases published original figures have been corrected or revised in later publications of the same agency. These discrepancies are usually of small magnitude and where they occur, the most recent figures of the Iowa Geological Survey have been used in this report.

The work of assembling the report was begun by the Iowa State Planning Board under the immediate supervision of R. H. Matson and later of O. H. Baldwin. When the existence of the Planning Board was terminated in 1939 the project was incomplete. At that time the columnar diagram for total mineral production had been completed to 1935, the tables had been prepared up to include 1936, the plate showing the geology and distribution of mineral production had been completed and the columnar diagrams for individual minerals had been outlined. The Planning Board, therefore, is responsible for the plan of the report and for a considerable part of its preparation. The Iowa Geological Survey has brought up to date and checked all tables and diagrams and has prepared the accompaning discussion.

\section{Major Geological Systems of Iowa}

Rocks of ten major geologic subdivisions occur at the surface in Iowa. In the order of decreasing age they are: Pre-Cambrian, Cambrian, Ordovician, Silurian, Devonian, Mississippian, Pennsylvanian, Permian(?), Cretaceous, and Pleistocene (including Recent). Materials composing the. Pleistocene are almost entirely unconsolidated, all others are considered to be consolidated.

Pleistocene deposits cover much of the surface of the state. They consist of glacial and interglacial clays, silts, loess, sands and gravels. Much of the sand and gravel was deposited by water associated with 
the glaciers. Glacial sand and gravel is the chief source of supply for the sand and gravel industry. The clays, which are chiefly glacial, have been sparingly used for the manufacture of clay products, but normally they are not suitable for this purpose. The loess has been somewhat more widely used for clay product manufacture.

The generalized geologic map (Plate I, figure D) shows the distribution of the consolidated rocks in Iowa which occur at the surface or which immediately underlie the glacial drift and other younger deposits. The best exposures of consolidated rocks occur in the northeast corner of the state, in the Mississippi River and Missouri River valleys and in the valleys of major tributary streams. Elsewhere they are masked by overlying Pleistocene deposits except for occasional exposures on the uplands.

Outcrops of pre-Cambrian rocks are limited in Iowa to the extreme northwestern corner of the state. The only formation exposed is a quartzite which has been utilized to a limited extent in the past for crushed stone and building material.

Cambrian rocks, composed primarily of sandstones with minor amounts of limestone, dolomite and shale, are limited in exposure area to northeastern Iowa. The sandstones and limestones have been used for building purposes and for crushed stone.

Formations of the Ordovician system are exposed only in the northeastern part of Iowa. They are made up of shales, limestones, dolomites, and sandstones, all of which have been developed commercially.

The outcrop area of the Silurian system is limited to east-central Iowa. It is composed essentially of dolomites which are used for building and crushed stone.

Rocks of the Devonian also form a band of outcrop in the eastern and north-central portions of the state. The formations are chiefly limestones, shales and dolomites. The limestones are used for crushed rock and by four of the six cement plants in the state; the shales furnish raw materials for clay products and cement manufacture.

Mississippian rocks, composed essentially of limestones and shales, form a band of outcrop from the southeastern corner to the northcentral portion of the state. The limestones are utilized for crushed stone, the shales for making clay products. A minor amount of gypsum has been mined from the Mississippian.

The Pennsylvanian system of rocks, often referred to as the "Coal Measures," is made up chiefly of shales, limestones, sandstones, coals, 
and underclays. It has a larger outcrop area (Plate I, figure D) and contributes more materials to the mineral industries than any other system in the state. From the Pennsylvanian comes all of the coal mined in Iowa, large volumes of shale for clay products and cement, and limestone for cement and crushed stone.

Rocks of the Permian (?) system, made up of red and green shales and gypsum, are restricted in Iowa to a small area in the vicinity of Fort Dodge which is too small to show on the accompanying map. Most of the-gypsum extracted in the state has been obtained from the Permian (?).

Cretaceous deposits, composed of shales, loosely consolidated sandstones and conglomerates and a minor amount of limestone, occur in northwestern Iowa and in scattered areas in the southwestern portion of the state. They are exploited chiefly for shales used in the making of clay products and for road-making materials derived from the sandstones and conglomerates.

\section{Geographical Distribution of Mineral Production}

The geographical distribution of the various mineral products may be seen from Plate I, figures $A, B$ and $C$. These maps show that the eastern and central portions of the state lead in the number of producers and that there are comparatively few producers in the western portion, particularly in the extreme northwest.

All of the cement produced in Iowa is manufactured in six large plants (Plate I, figure A). Two are located in Cerro Gordo county, two in Polk county and one each in Scott and Pocahontas counties. Raw materials are obtained chiefly from the immediate vicinity of the plants; those for the plants in Polk county are derived from Pennsylvanian rocks, all others come from the Devonian.

Clay, including shale, has been produced for commercial purposes from many geological horizons from almost all portions of the state, but utilization has been most concentrated in the central, north-central and southeastern areas. The distribution of operators for 1920 and for 1936 is shown by Plate I, figure C.

Coal is extracted chiefly from the central and southern portion of the state, where Pennsylvanian rocks are at or near the surface. An iclea of the distribution of production can be obtained from Plate I, figure B which shows that in 1935 there were 262 operators in 23 


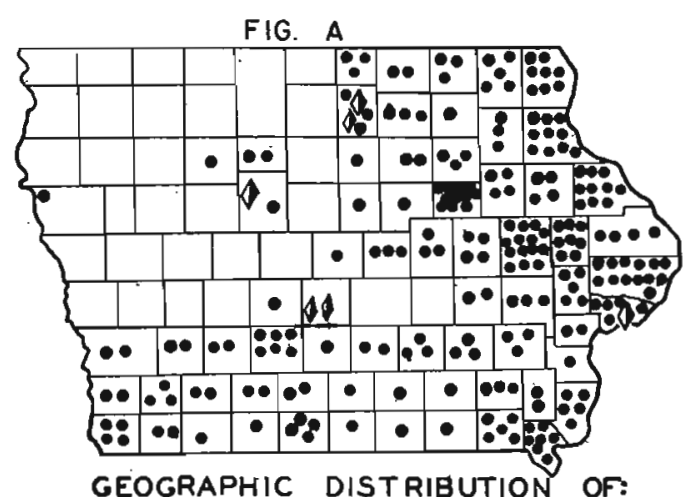

- LIME \& LIMESTONE PRODUCERS FOR 1936, PEAK YEAR. $\checkmark$ CEMENT PRODUCERS FOR 1936.

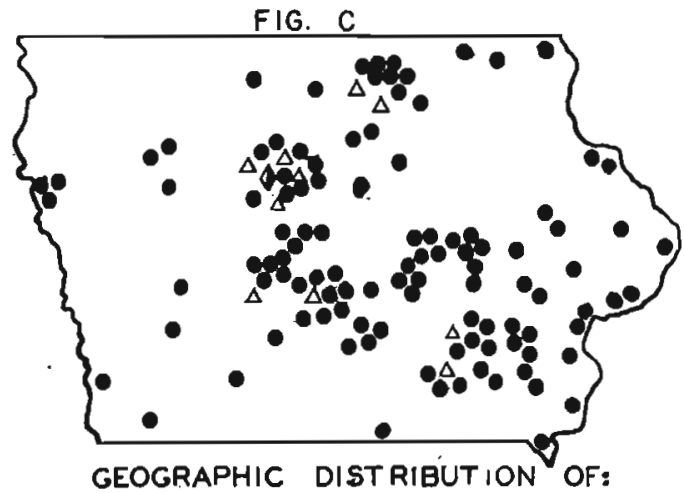

- gypsum producers for 1936

- clay \& clay products producers for 1020 , peak year. a clay clar products producers for 1936.

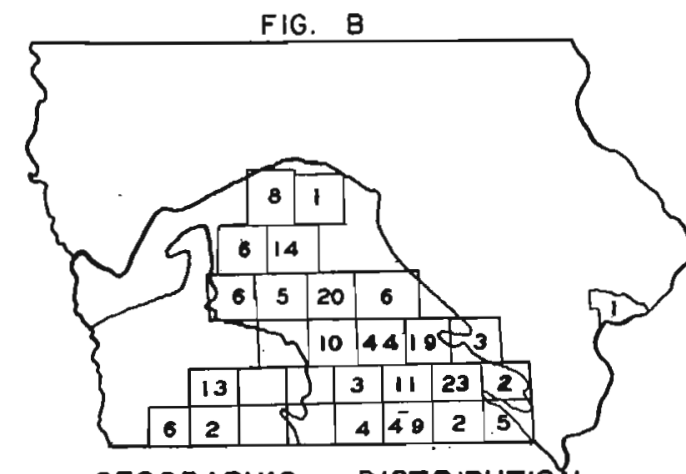

GEOGRAPHIC DISTRIBUTION

OF COAL FOR I935

NUMBERS REFER TO NUMBER OF PRODUCERS IN EACH TERRITORY

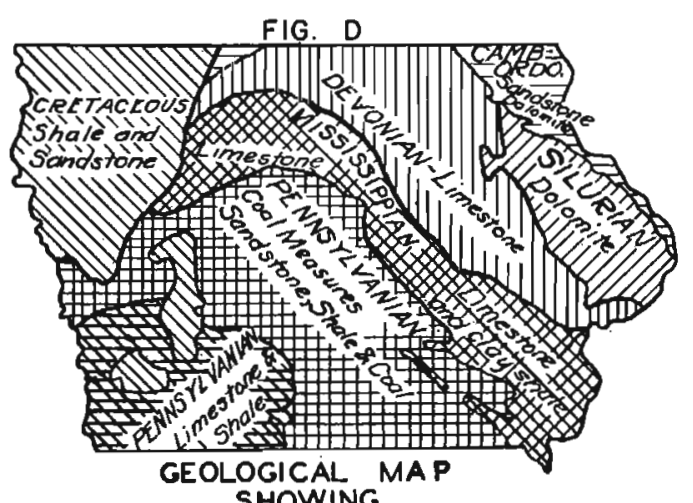

MAJOR GEOLOGICAL DIVISIONS 
counties. These operators were chiefly those producing more than 1,000 tons of coal annually. In addition there were a large number of smaller producers.

The gypsum industry in Iowa is centered in a relatively small area in the immediate vicinity of Fort Dodge (Plate I, figure C), although some production has been obtained in the vicinity of Centerville in Appanoose county. The source of raw material at Fort Dodge is Permian (?), at Centerville Mississippian.

Limestone production is widespread in Iowa. As shown by Plate I, figure $A$, all counties but two in the eastern half and all counties in the southern third of the state produced this material in 1936. Output in northwestern Iowa is limited because limestone is only sparingly present there and where it does occur conditions are such that profitable extraction is difficult. All of the major geologic subdivisions except the Pleistocene and pre-Cambrian have yielded limestone production of commercial value in Iowa.

The production of sand and gravel is more widespread than for any other mineral product in the state. These materials are found at or near the surface in all parts of Iowa and have been exploited in every county, although the major portion is extracted in the northern and southeastern areas. They are chiefly Pleistocene in age although the Cretaceous has furnished considerable production.

\section{Annual Total Mineral Production}

Plate II represents the total mineral production in the state for the period of this report by value of individual minerals produced. The entire circle is equivalent to 100 per cent of total production of all minerals, and the segments are scale representations of the percentage of individual total productions.

The total value of coal led all other minerals for the period 18951938 with a cumulative value of 48.7 per cent of the total of all minerals produced. Cement ranked second with a value of 17.5 per cent, and clay and clay products third with a value representing 17.2 per cent of the total, followed by gypsum ( 8.3 per cent), lime and limestone (4.2 per cent), and sand and gravel ( 4.0 per cent). The remainder of the percentage is taken up by other minerals.

Table I shows that the total value of mineral production in Iowa advanced steadily from 1895 through 1916, except for a slight decline 
TOTAL MINERAL PRODUCTION

IN IOWA. 1895-1938

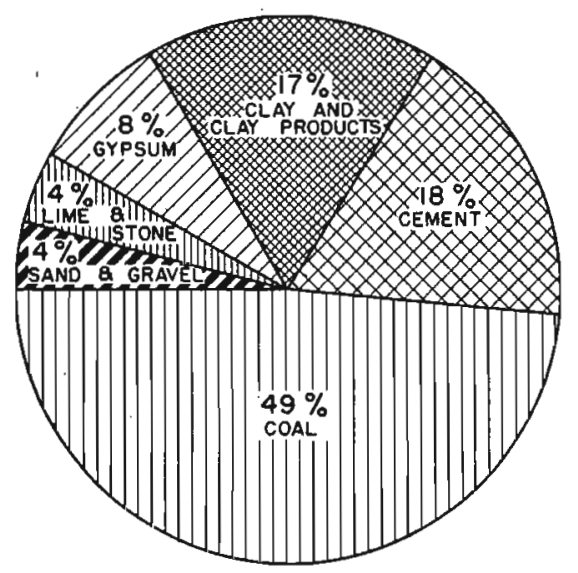


TABLE I

Annual Total Mineral Production in Iozea-1895-1938

\begin{tabular}{|c|c|c|c|c|c|}
\hline Year & Value & $\begin{array}{l}\text { Average value } \\
\text { for two year } \\
\text { period }\end{array}$ & Year & Value & $\begin{array}{c}\text { Average value } \\
\text { for two year } \\
\text { period }\end{array}$ \\
\hline $\begin{array}{l}1895 \\
1806\end{array}$ & & $\$ 7,240,146$ & 1917 & $\$ 39,336,372$ & $\$ 39,039,190$ \\
\hline $\begin{array}{l}1090 \\
1897\end{array}$ & $\$ 7,676,181$ & 7731.880 & 1919 & $37,882,183$ & 47.566 .250 \\
\hline $\begin{array}{l}1898 \\
1899\end{array}$ & $\begin{array}{l}7,787,579 \\
9537948\end{array}$ & & 1920 & $\begin{array}{l}57,250,317 \\
35,625,170\end{array}$ & \\
\hline $\begin{array}{l}1099 \\
1900\end{array}$ & $\begin{array}{r}9,531,948 \\
10,401,661\end{array}$ & $9,969,804$ & $\begin{array}{l}1921 \\
1922\end{array}$ & $\begin{array}{l}35,625,170 \\
36,189,398\end{array}$ & $35,907,284$ \\
\hline $\begin{array}{l}1901 \\
1902\end{array}$ & $\begin{array}{l}12,204,160 \\
12517,501\end{array}$ & $12,360,830$ & 1923 & $\begin{array}{l}46,237,521 \\
40,470.071\end{array}$ & $43,354,246$ \\
\hline 1903 & $14,596,708$ & 14775854 & 1925 & $38,393,742$ & \\
\hline 1904 & $14,955,000$ & & 1926 & $35,985,779$ & $37,189,760$ \\
\hline $\begin{array}{l}1905 \\
1906\end{array}$ & $\begin{array}{l}15,103,046 \\
16414,447\end{array}$ & $15,758,747$ & $\begin{array}{l}1927 \\
1928\end{array}$ & $\begin{array}{l}33,442,891 \\
35,501,033\end{array}$ & $34,471,962$ \\
\hline 1907 & $17,627,925$ & $17,859,186$ & 1929 & $35,961,008$ & $34,652,764$ \\
\hline $\begin{array}{l}1908 \\
1909\end{array}$ & $\begin{array}{l}18,090,447 \\
20,365,721\end{array}$ & & 1931 & $\begin{array}{r}3,344,5<0 \\
21,626,332\end{array}$ & \\
\hline 1910 & $22,744,572$ & $21,555,146$ & 1932 & $18,522,625$ & $20,074,478$ \\
\hline 1911 & $21,119,111$ & $22,014,588$ & 1933 & $15,154,652$ & $17,240,416$ \\
\hline $\begin{array}{l}1912 \\
1913\end{array}$ & $\begin{array}{l}22,910,000 \\
25,612,345\end{array}$ & & 1935 & $21,709,817$ & \\
\hline 1914 & $26,301,865$ & $25,957,105$ & 19 & $28,359,140$ & $25,034,478$ \\
\hline 1915 & $\begin{array}{l}27,062,950 \\
30,210,284\end{array}$ & $28,636,617$ & $\begin{array}{l}1937 \\
1938\end{array}$ & $\begin{array}{l}26,941,350 \\
25,159,058\end{array}$ & $26,050,204$ \\
\hline
\end{tabular}

in 1911. Output was abnormally high during the war years of 19171918 and the post-war years 1919-1920. In. 1920 mineral production reached a total value of $\$ 57,250,317$, the greatest ever attained in Iowa and more than 11 millions of dollars greater than for 1923 the next most productive year. After a sharp decline in the period 19211922 , and the strong recovery in 1923, total value began a downward trend during the year following, which continued until 1928-1929 when gains were slight. The depression which began in late 1929 caused some decrease in total value in 1930, but the full effect of general conditions was reflected in large decreases in the value of minerals produced in Iowa from 1931 through 1933. In 1933 total production amounted to $\$ 15,154,652$ and was lower than for any year since 1905. Recovery began in 1934 and continued through 1936. The recession of 1937-1938 caused a drop in mineral production in the latter year.

Plate III presents the relationships between the various mineral commodities represented. It shows by two year periods the total value of mineral production, the value of individual minerals produced and the percentage of the biennial total represented by each commodity.

The combined industries showed a general upward trend from 189.5 to a maximum in 1919-1920, a general downward trend to 1933-1934 


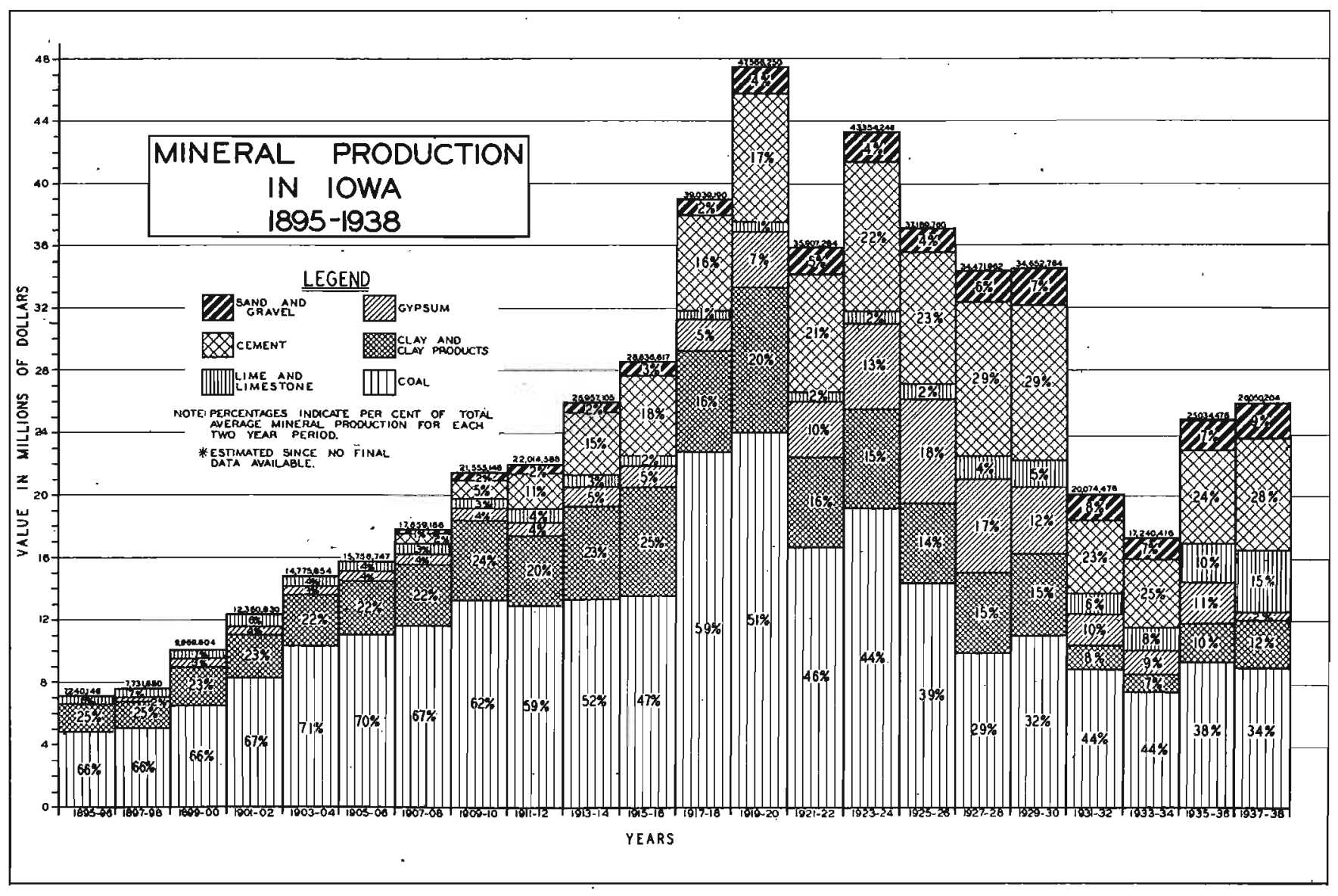




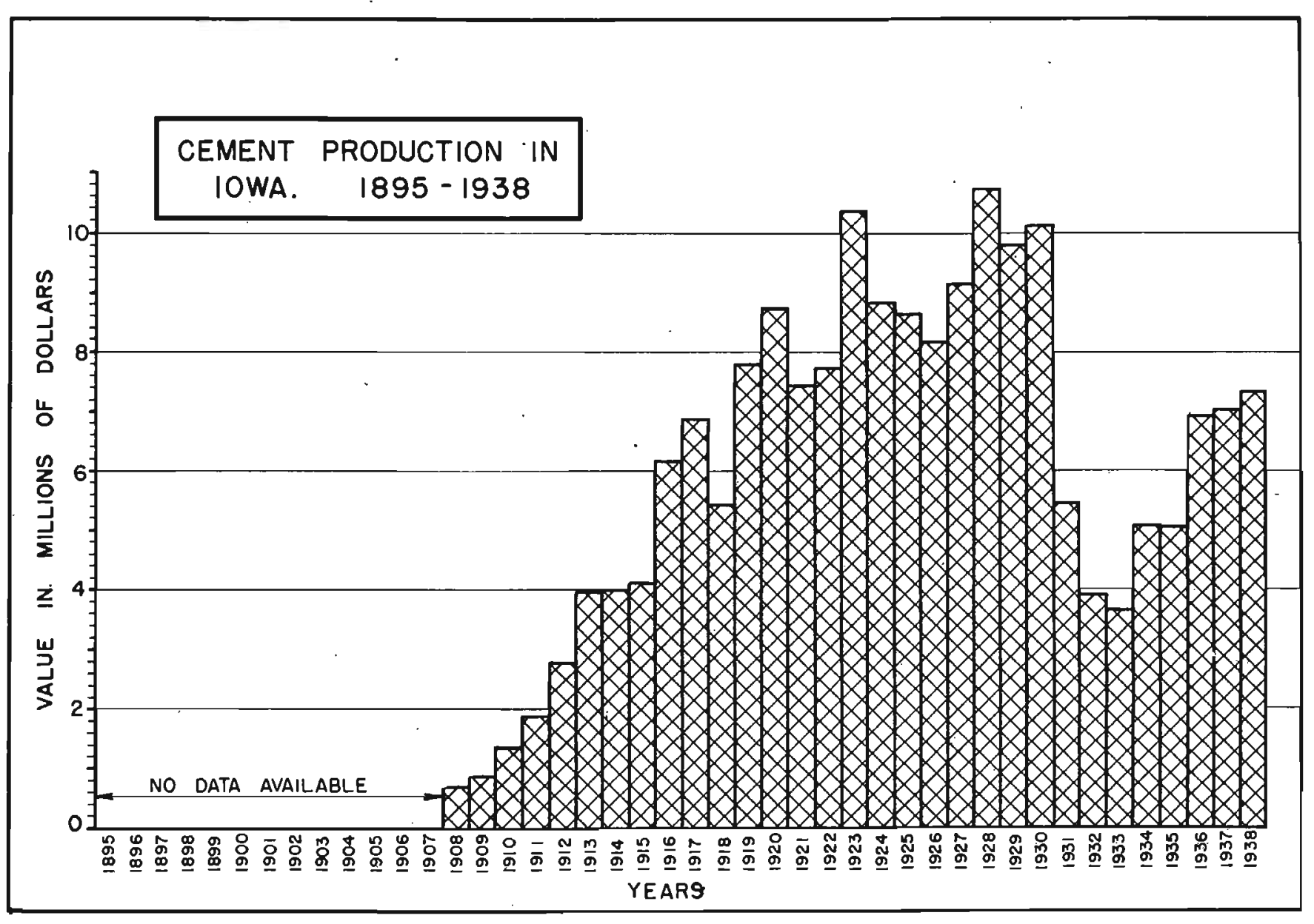


and an uptrend until 1938. Coal, and clay and clay products, two of the leading mineral products followed these trends while other mineral commodities reached maximum productions after 1920 .

The ranking positions of the various minerals over the 43-year period show coal to be the outstanding leader although output of this resource decreased in relative value after 1917-1918. Clay and clay products which ranked second from 1895 to 1920 yielded its place to cement in the ensuing years. Sand and gravel increased steadily from 1 per cent of the total mineral production in 1907-1908 to 9 per cent in 1935. Lime and limestone represented from 7 to 3 per cent of the total from 1895 to the beginning of the war period, dropped as low as 1 per cent in 1919-1920, then advanced steadily to 8 per cent of the total in 1935.

TABLE II

Cement Production in Iowa - 1895-1938

\begin{tabular}{|c|c|c|c|c|}
\hline \multirow[b]{3}{*}{ Year } & \multicolumn{4}{|c|}{ Shipments } \\
\hline & \multirow[b]{2}{*}{$\begin{array}{l}\text { Quantity } \\
\text { (barrels) }\end{array}$} & \multirow[b]{2}{*}{ Value } & \multicolumn{2}{|c|}{ Average for two year period } \\
\hline & & & Value & $\begin{array}{c}\text { Percent of } \\
\text { total a }\end{array}$ \\
\hline \multicolumn{5}{|c|}{ 1895-1908 No data available } \\
\hline 1908 & & $\$ 690,105$ & & 2 \\
\hline $\begin{array}{l}1909 \\
1910\end{array}$ & & $\begin{array}{r}862,000^{\mathrm{b}} \\
1,386,000^{\mathrm{b}}\end{array}$ & $\$ 1,124,000$ & 5 \\
\hline 1911 & $1,952,590$ & $1,881,253$ & 2335824 & 11 \\
\hline 1912 & $3,190,354$ & $2,790,396$ & $2,335,0<4$ & 11 \\
\hline $\begin{array}{l}1913 \\
19.14\end{array}$ & $\begin{array}{l}3,455,800 \\
4,224,076\end{array}$ & $\begin{array}{l}3,972,876 \\
4,008,915\end{array}$ & $3,9900,895$ & 15 \\
\hline 1915 & $4,590,336$ & $4,119,952$ & $5,142.749$ & 18 \\
\hline $\begin{array}{l}1916 \\
1917\end{array}$ & $4,853,789$ & $6,165,547$ & & \\
\hline 1918 & $\begin{array}{l}4,428,705 \\
3,188,669\end{array}$ & $5,423,926$ & $6,147,394$ & 16 \\
\hline 1919 & $4,569,110$ & $7,798,347$ & 8270600 & 17 \\
\hline 1920 & $4,421,783$ & $8,742,854$ & $0,2 \gamma 0,0$ N & $1 /$ \\
\hline $\begin{array}{l}1921 \\
1922\end{array}$ & $\begin{array}{l}4,151,439 \\
4,475,074\end{array}$ & $\begin{array}{l}7,439,983 \\
7,709,313\end{array}$ & $7,574,648$ & 21 \\
\hline 1923 & $5,570,675$ & $10,351,971$ & 0581770 & 22 \\
\hline 1924 & $4,881,613$ & $8,811,587$ & $9,501,1 / 9$ & 22 \\
\hline $\begin{array}{l}1925 \\
1926\end{array}$ & $\begin{array}{l}4,856,849 \\
4,788,639\end{array}$ & $\begin{array}{l}8,674,563 \\
8,167,341\end{array}$ & $8,420,952$ & 23 \\
\hline 1927 & $5,661,234$ & $9,124,405$ & 0020621 & 20 \\
\hline 1928 & $6,880,731$ & $10,734,838$ & $9,9<9,021$ & 29 \\
\hline $\begin{array}{l}1929 \\
1930\end{array}$ & $\begin{array}{l}6,586,111 \\
7,035,252\end{array}$ & $\begin{array}{r}9,781,159 \\
10,107,584\end{array}$ & $9,944,371$ & 29 \\
\hline 1931 & $5,790,087$ & $5,453,320$ & 4680.373 & 23 \\
\hline 1932 & $4,373,642$ & $3,907,427$ & & \\
\hline $\begin{array}{l}1933 \\
1934\end{array}$ & $\begin{array}{l}2,710,656 \\
3,340,049\end{array}$ & $\begin{array}{l}3,051,921 \\
5,094,922\end{array}$ & $4,373,421$ & 25 \\
\hline 1935 & $3,203,301$ & $5,072,098$ & 5.990162 & 24 \\
\hline 1936 & $4,407,624$ & $6,908,225$ & & 24 \\
\hline $\begin{array}{l}1937 \\
1938\end{array}$ & $\begin{array}{l}4,598,453 \\
4,759,390\end{array}$ & $\begin{array}{l}7,046,021 \\
7,327,048\end{array}$ & $7,186,534$ & 28 \\
\hline
\end{tabular}

a Percent of total value of all minerals produced in Iowa for the two year period designated. b Estimated. 


\section{Cement}

The history of cement production is given in Plate IV and Table II. Prior to 1931 the cement industry presented an enviable record of advancement in Iowa. In 1908, the first year for which data are available, the value of cement produced was $\$ 690,105$ which represented 4 per cent of the total mineral production of the state; by 1923 it had increased to $\$ 10,351,971$, about 20 per cent of the state total for all minerals, and in that time decreases occurred in only two years, 1918 and 1921. Production followed a moderate downward trend from 1924. to 1926, but the ensuing upswing included the highest production value recorded in Iowa. This peak was attained in 1928 when the value was $\$ 10,734,838$. Values remained relatively stable until 1930 , but in 1931, with building construction at an extremely low level, cement production suffered a sharp decline. Further decreases in 1932 and 1933 depressed the annual value in the latter year to $\$ 3,651,921$ which was lower than for any year after 1912. Recovery of building construction was reflected in sharp increases in cement values in 1934 and this uptrend continued through 1938.

Quantity and value of production are not directly comparable because of variations in price. The peak quantity production was reached in 1930 when it amounted to $7,035,252$ tons valued at $\$ 10,107,584$, but in 1928 an output of $6,880,731$ tons was valued at $\$ 10,734,838$.

Since 1921 cement has outranked all other mineral products except coal in annual output value, in spite of the facts that large scale production of cement began as late as 1908 and the industry suffered exceptional declines during the depression.

\section{Clay and Clay Products}

The clay industry, including production of raw clay, shale and clay products ranked second to coal in total value from 1895 to 1921. Since then it experienced reversals which placed it fifth in rank in 1936.

As shown by Plate $\mathrm{V}$ and Table III advancement was relatively steady from 1895 to 1917 with increases in production returns for all years except 1896, 1900, 1905 and 1911. A sharp decline in 1918 was followed in 1919 by an even greater advance, and in 1920 an output valued at $\$ 10,489,232$ represents a record for the period of this report. After a decrease in 1921 the industry remained fairly stable until 1929 except for a rise in 1923 and an equivalent drop in 1926. 


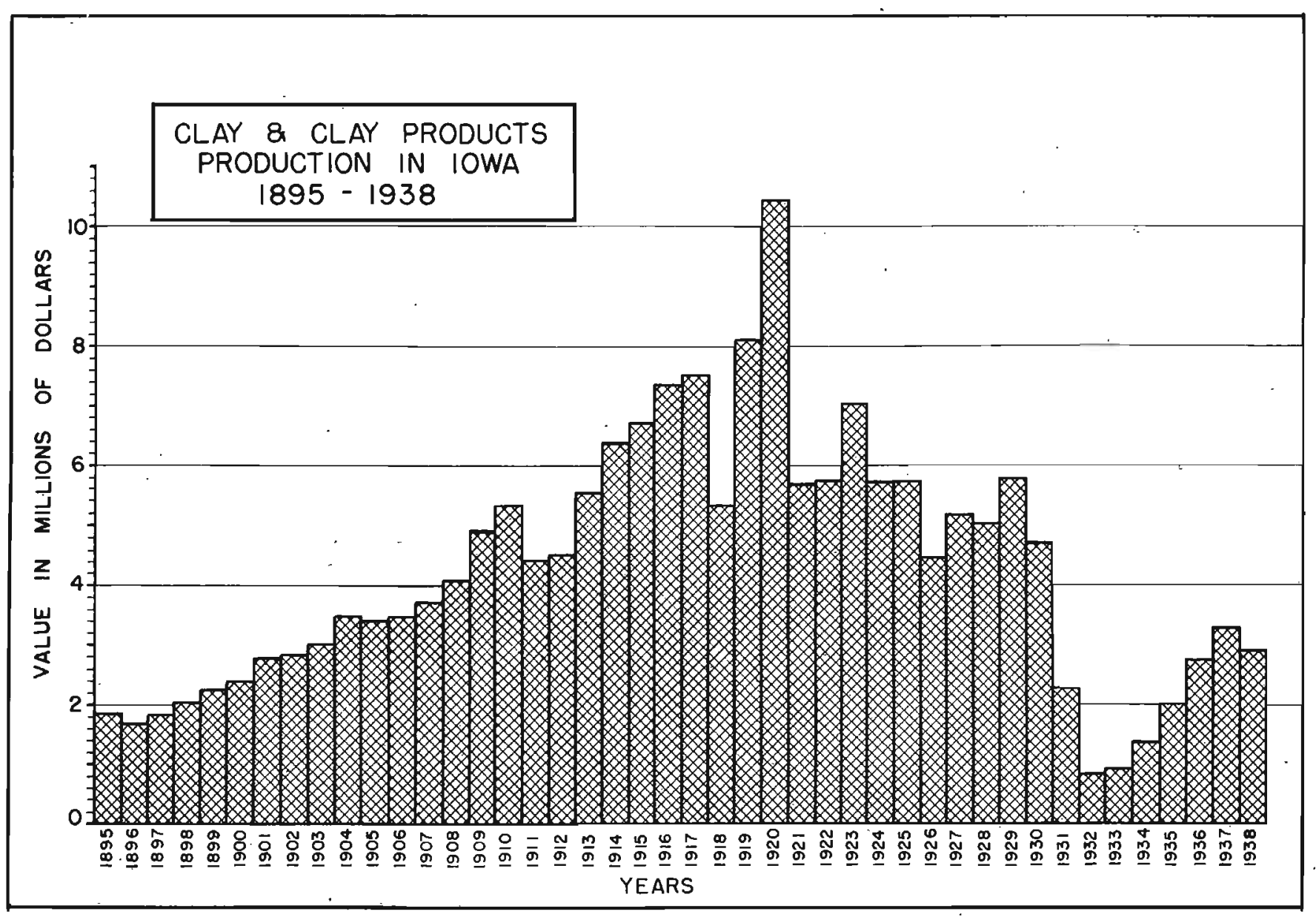


TABLE III

Clay and Clay Products Production in Iowa - 1895-1938

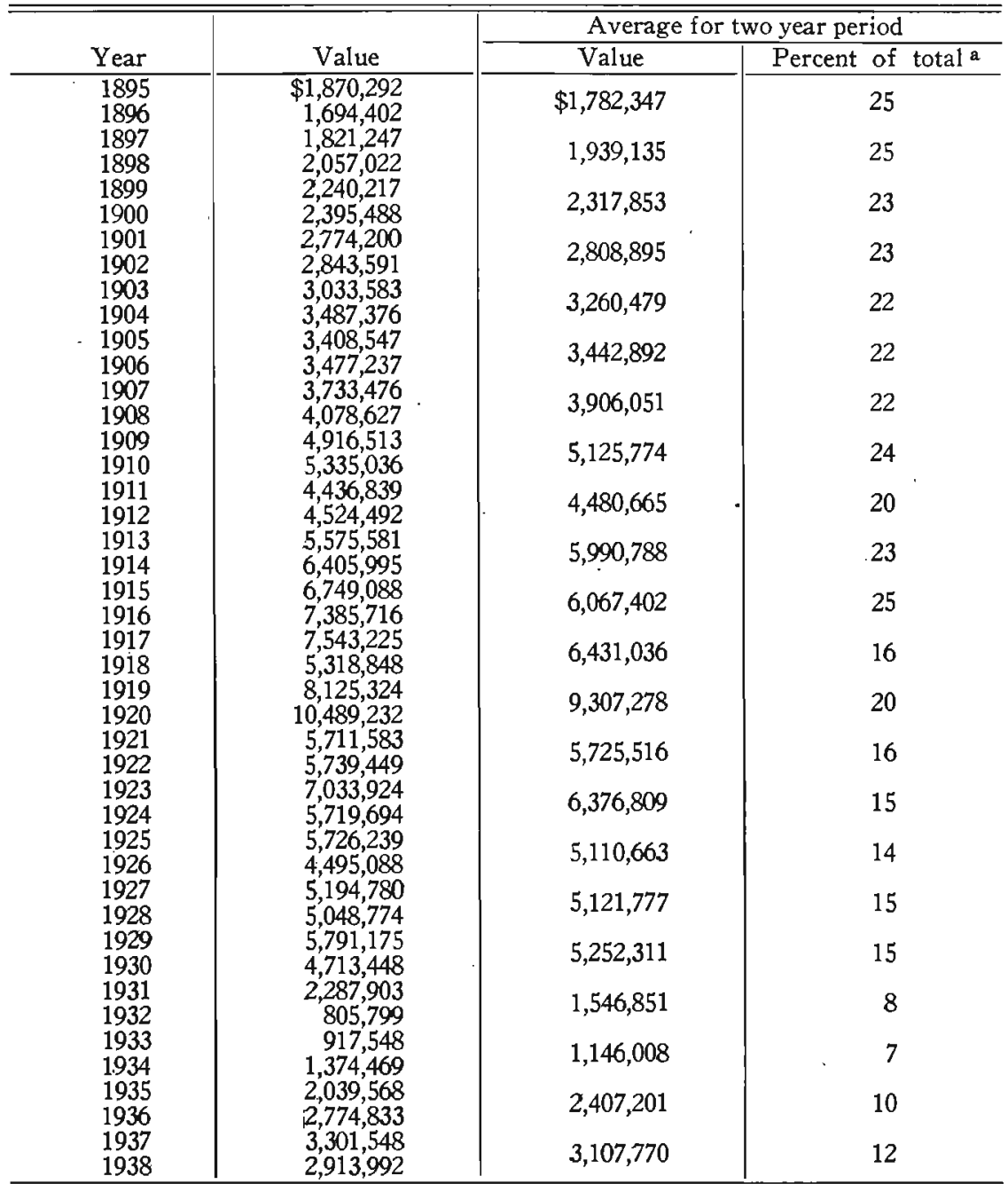

a Percent of total value of all minerals produced in Iowa for the two year period designated.

The years of the depression, 1930-1932, were disastrous for the clay industry. Total values dropped from $\$ 5,791,175$ in 1929 to $\$ 805$, 375 in 1930. The latter value is far. below that of any year after 1895 and less than one-tenth of the peak production value of 1920 .

Recovery began in 1933 and continued through 1937 although total value was considerably below average for this period. The effect of the recession which began in late 1937 and continued into early 1938 
TABLE IV

Coal Production in Iowa-1895-1938

\begin{tabular}{|c|c|c|c|c|}
\hline \multirow[b]{2}{*}{ Year } & \multirow[b]{2}{*}{$\begin{array}{c}\text { Quantity } \\
\text { (tons) }\end{array}$} & \multirow[b]{2}{*}{ Value } & \multicolumn{2}{|c|}{ Average for two year period } \\
\hline & & & Value & $\begin{array}{c}\text { Percent of } \\
\text { total a }\end{array}$ \\
\hline 1895 & $4,156,074$ & $\$ 4,982,102$ & $\$ 4,805,062$ & 66 \\
\hline 1897 & $4,523,494$ & $5,098,103$ & 5.110 .645 & 66 \\
\hline $\begin{array}{l}1898 \\
1899\end{array}$ & $\begin{array}{l}4,500,810 \\
4928,477\end{array}$ & $5,123,187$ & & \\
\hline $\begin{array}{l}1899 \\
1900\end{array}$ & $\begin{array}{l}4,928,47 / \\
5,105,151\end{array}$ & $\begin{array}{l}0,137,570 \\
6,977,466\end{array}$ & $6,557,521$ & 66 \\
\hline $\begin{array}{l}1901 \\
1902\end{array}$ & $\begin{array}{l}5,663,016 \\
5,527,263\end{array}$ & $\begin{array}{l}8,051,806 \\
8,660,287\end{array}$ & $8,356,047$ & 67 \\
\hline $\begin{array}{l}1903 \\
1904\end{array}$ & $\begin{array}{l}6,365,233 \\
6,507655\end{array}$ & $\begin{array}{l}10,439,139 \\
10,439,496\end{array}$ & $10,439,317$ & 71 \\
\hline 1905 & $6,798,609$ & $10,586,381$ & $11,102,918$ & 70 \\
\hline $\begin{array}{l}1906 \\
1907\end{array}$ & $\begin{array}{l}7,266,224 \\
7,574,322\end{array}$ & $\begin{array}{l}11,619,455 \\
12,258,012\end{array}$ & & \\
\hline 1908 & $7,161,310$ & $11,706,402$ & $11,982,207$ & $6 z$ \\
\hline $\begin{array}{l}1909 \\
1910\end{array}$ & $\begin{array}{l}7,757,762 \\
7,928,120\end{array}$ & $\begin{array}{l}12,793,628 \\
13,903,913\end{array}$ & $13,348,770$ & 62 \\
\hline $\begin{array}{l}1911 \\
1012\end{array}$ & $\begin{array}{l}7,331,648 \\
7280,520\end{array}$ & $\begin{array}{l}12,663,507 \\
13,088\end{array}$ & $12,907,798$ & 59 \\
\hline 1913 & $7,525,936$ & $13,496,710$ & $13,430,390$ & 52 \\
\hline $\begin{array}{l}1914 \\
1915\end{array}$ & $\begin{array}{l}7,451,022 \\
7,614,143\end{array}$ & $\begin{array}{l}13,364,070 \\
13,577,608\end{array}$ & & \\
\hline 1916 & $7,260,800$ & $13,530,383$ & $13,553,995$ & 47 \\
\hline $\begin{array}{l}1917 \\
1918\end{array}$ & $\begin{array}{l}8,965,830 \\
8,192,195\end{array}$ & $\begin{array}{l}21,096,408 \\
24,703,237\end{array}$ & $22,899,822$ & 59 \\
\hline $\begin{array}{l}1919 \\
1020\end{array}$ & $5,624,692$ & $17,352,620$ & $24,073,233$ & 51 \\
\hline 1921 & $4,531,392$ & $17,256,800$ & 16.687900 & 46 \\
\hline 1922 & $4,335,161$ & $16,119,000$ & & \\
\hline 1923 & $\begin{array}{l}5,710,735 \\
54684\end{array}$ & $\begin{array}{l}20,517,000 \\
18,097,000\end{array}$ & $19,307,000$ & 44 \\
\hline 1925 & $4,714,843$ & $14,807,000$ & $14,510,500$ & 39 \\
\hline $\begin{array}{l}1926 \\
1927\end{array}$ & $\begin{array}{l}4,625,487 \\
2,949,622\end{array}$ & $\begin{array}{r}14,214,000 \\
9,304,000\end{array}$ & 001450 & \\
\hline 1928 & $3,683,635$ & $10,525,000$ & $9,914,500$ & 29 \\
\hline $\begin{array}{l}1929 \\
1930\end{array}$ & $\begin{array}{l}4,241,069 \\
3,892,571\end{array}$ & $\begin{array}{l}11,948,000 \\
10385000\end{array}$ & $11,166,500$ & 32 \\
\hline 1931 & $3,388,355$ & $8,575,000$ & $8,914,500$ & 44 \\
\hline $\begin{array}{l}1932 \\
1933\end{array}$ & $\begin{array}{l}3,862,435 \\
3,194,983\end{array}$ & $\begin{array}{l}9,254,000 \\
7,217,000\end{array}$ & 7530500 & \\
\hline 1934 & $3,366,992$ & $7,862,000$ & $7,539,300$ & 44 \\
\hline $\begin{array}{l}1935 \\
1936\end{array}$ & $\begin{array}{l}3,650,163 \\
3,960700\end{array}$ & $\begin{array}{l}9,002,000 \\
9,940,000\end{array}$ & $9,471,000$ & 38 \\
\hline $\begin{array}{l}1937 \\
1938\end{array}$ & $\begin{array}{l}3,637,054 \\
3,250,000^{\mathrm{b}}\end{array}$ & $\begin{array}{l}9,529,000^{\mathrm{b}} \\
8,340,000^{\mathrm{b}}\end{array}$ & $8,934,500$ & 34 \\
\hline
\end{tabular}

a Percent of total value of all minerals produced in Iowa for the two year period. designated.

b Estimated.

resulted in a drop in the output value of clay and clay products in the latter year.

\section{Coal}

For the details of coal production, see Plate VI and Table IV. The annual value of coal production showed a relatively steady increase from 1895 to 1916, although after 1902 the advance was not as rapid 


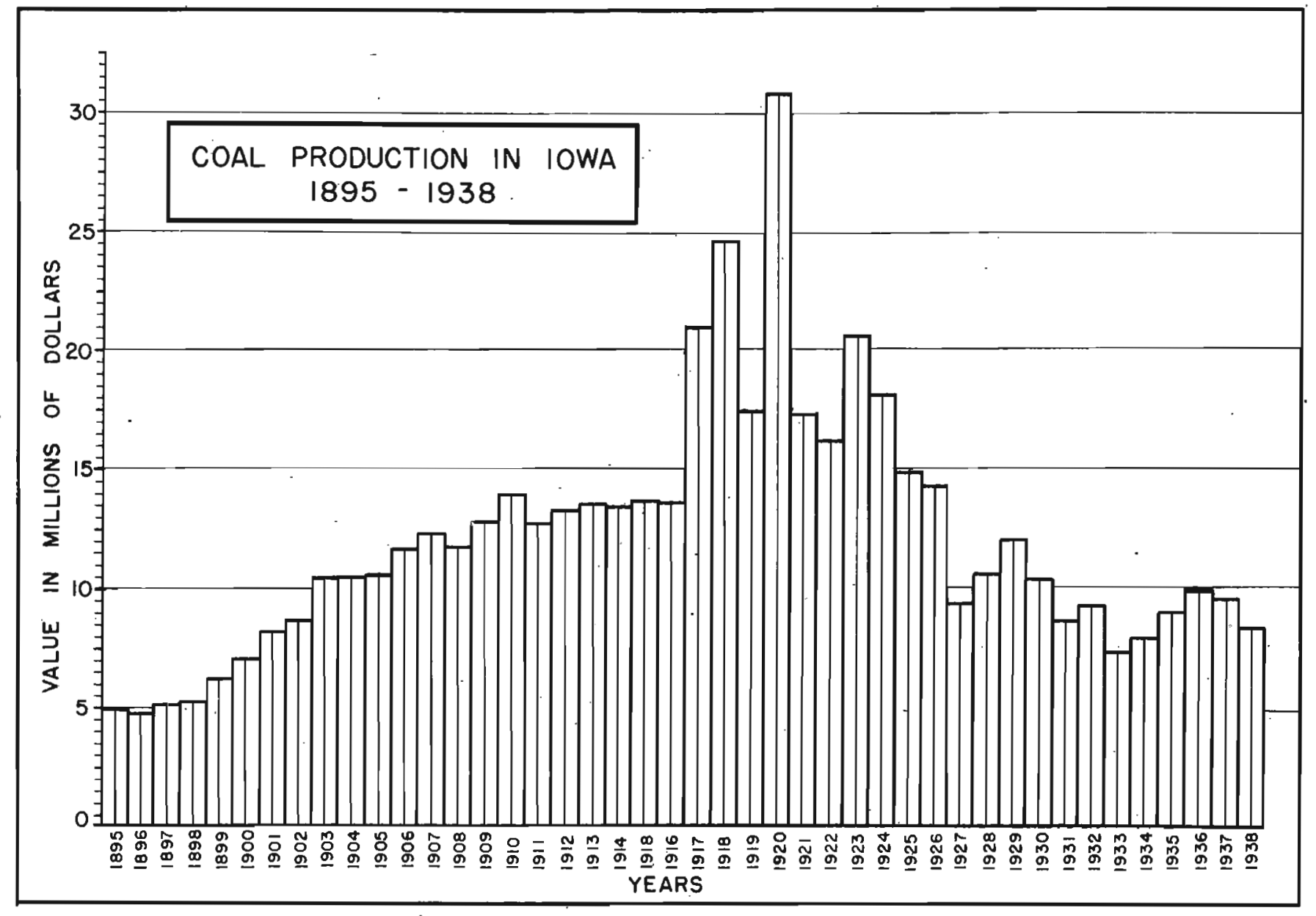


as it was prior to that year. War industries caused abnormally sharp increases in 1917 and 1918, but post-war conditions caused an almost equally sharp drop in 1919 . An output valued at $\$ 30,793,847$ in 1920 established an all-time production record in Iowa. After 1920 the trend was generally downward until 1933 although increases over the previous year occurred in 1923, 1928, 1929 and 1932. Coal reached the depression low in 1933 when production value was $\$ 7,217,000$ which was lower than any year since 1900 and represented a value of 23 per cent of the peak output of 1920. Production increased from 1933 through 1936, but in 1937 and 1938 the estimated value declined.

The quantity of coal produced followed in general the same trends as the total value. Notable differences, howeyer, are that peak quantity production was attained in 1917 when the output was $8,965,830$ tons, and the minimum production for the period of this report was 2,949, 622 tons in 1927. These apparent discrepancies between quantity and value are explained by variations in price.

\section{Gypsum}

Plate VII and Table V show trends in production of gypsum. Gypsum production followed a general upward trend from 1895 until 1927. Advancement was slow and erratic until 1916, but after that year gains were more rapid. Increases in value over the preceding year occurred in $1917,1919,1920,1922-1925$ and 1927. The greatest annual value of production on record for Iowa was attained in 1925 when it amounted to $\$ 6,734,271$ and in 1926 and 1927 the values were over 6.5 and 6.7 millions of dollars respectively. The years 1928-1933 were disastrous for the gypsum industry in the state; the value of production dropped at the rate of more than a million dollars a year for five successive years, and the low was reached in 1933 when the value was $\$ 1,357,407$. Recovery began in 1934 , however, and continued through 1936, the last year for which comparable figures are available.

The quantity of production was somewhat more uniform than was the value. The peak production of 723,942 tons was reached in 1927 and the depression low came in 1933 with an output of 163,243 tons.

It should be noted that the tables show quantities and values of calcined and uncalcined gypsum and that the columnar diagram is based on these figures rather than the value of crude gypsum mined, except 


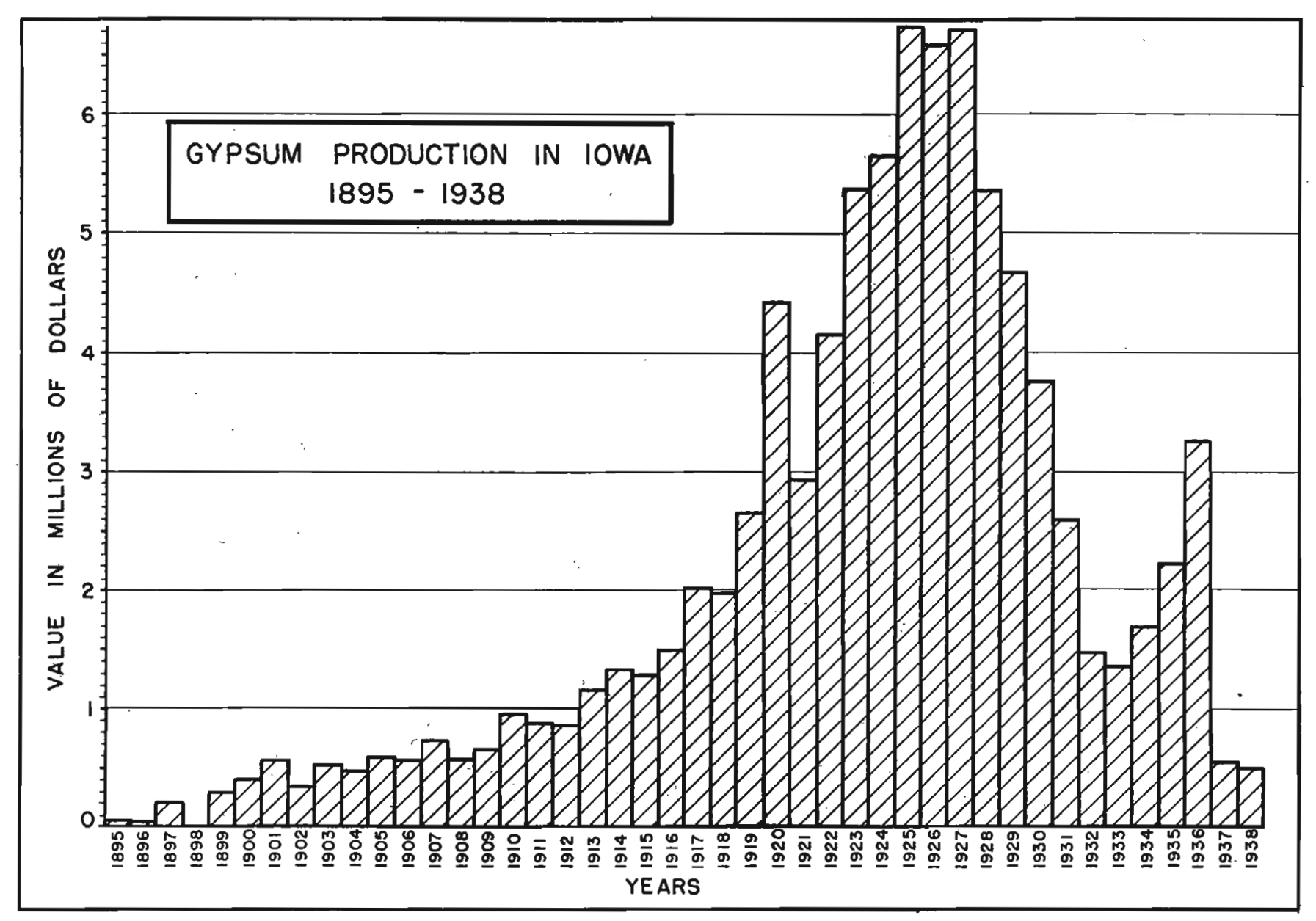


TABLE V

Gypsum Production in Iowia-1895-1938

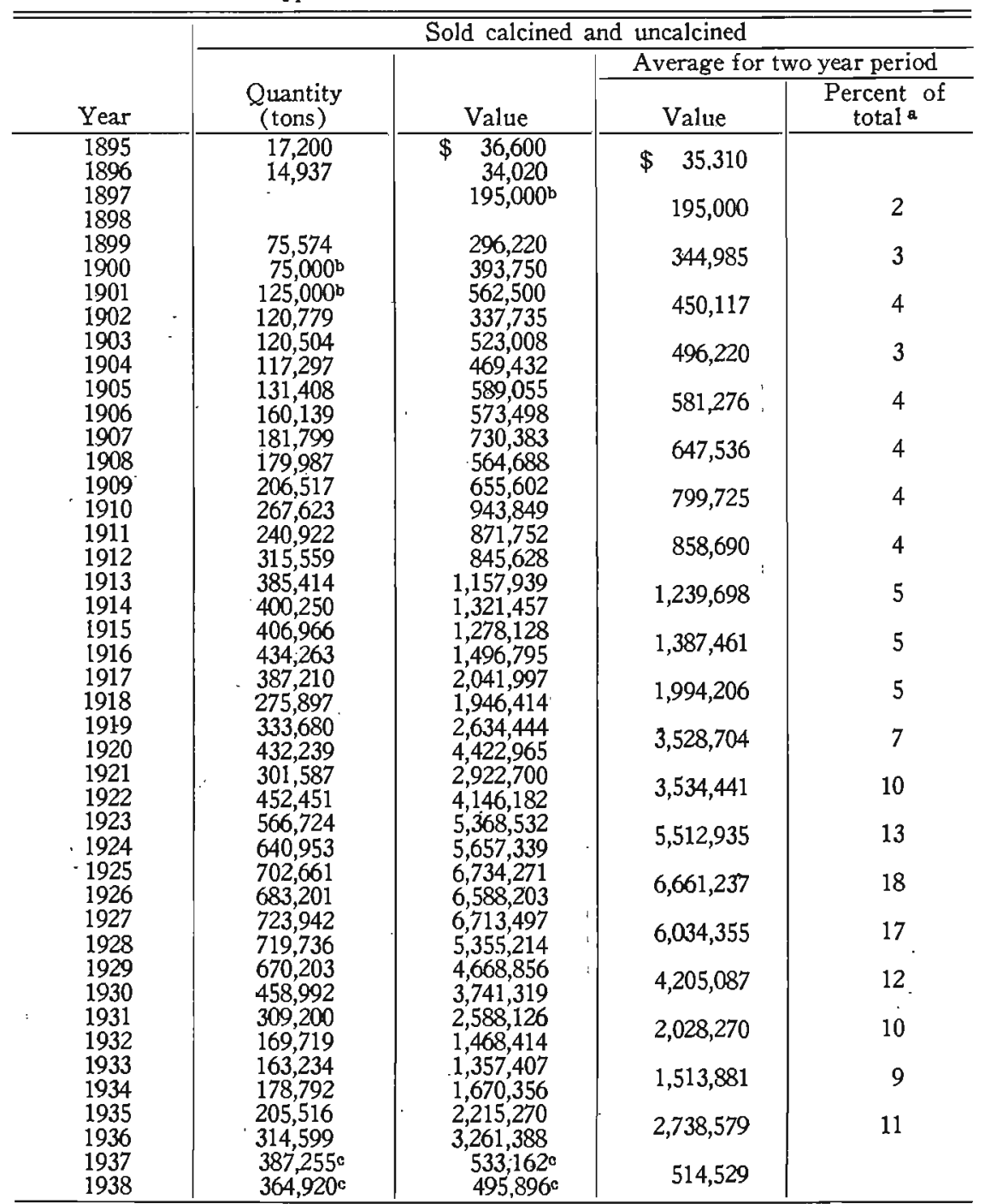

a Percent of total value of all minerals produced in Iowa for the two year period designated. b Estimated.

c Mined, not comparable to earlier years.

for 1937-1938 when the only figures available are for crude gypsum mined.

\section{Lime and Limestone}

Production of lime and limestone during the period 1895-1938 is unique in that it does not follow the trends of production of other 


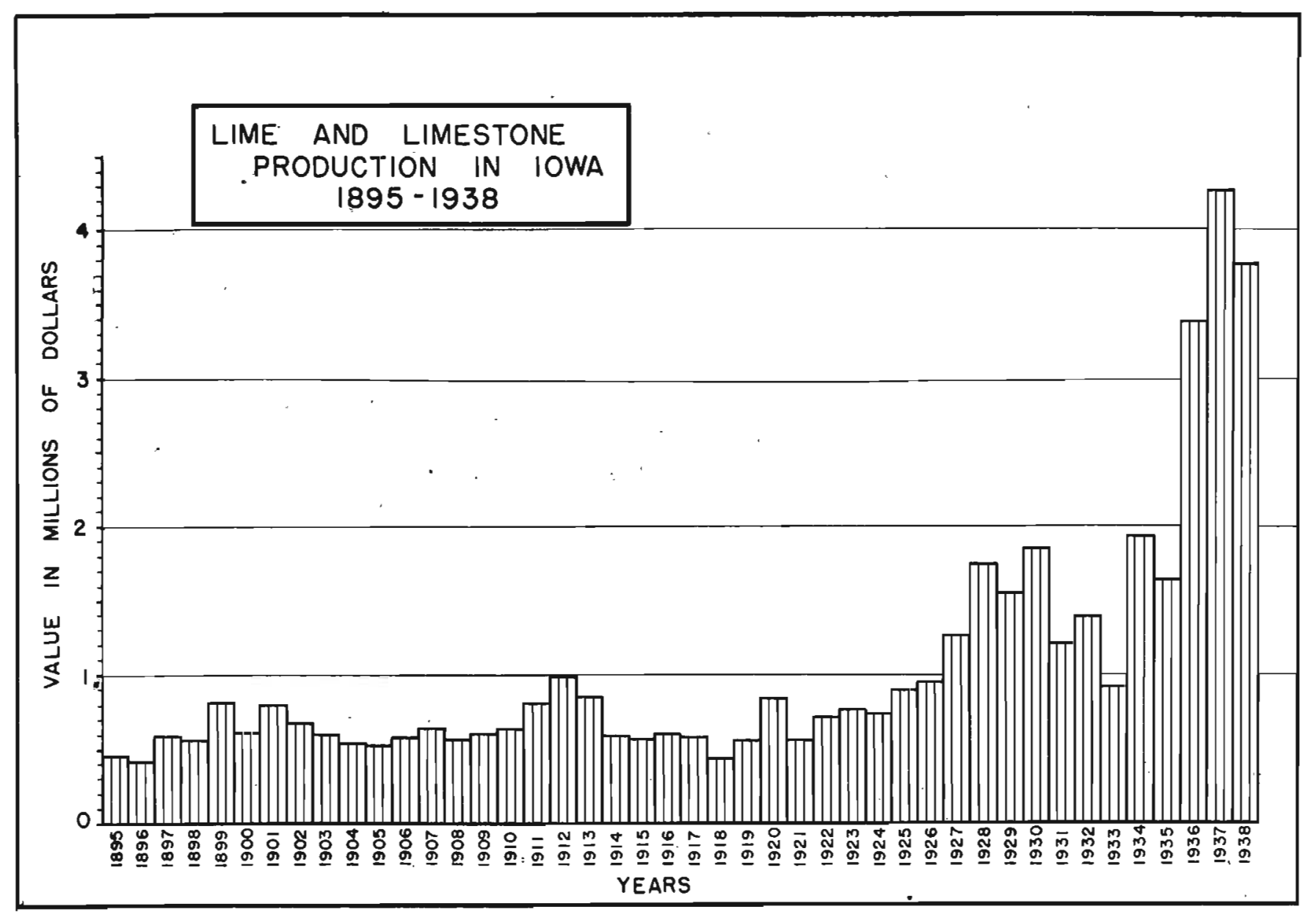


TABLE VI

Lime and Limestone Production in Iowa-1895-1938

\begin{tabular}{|c|c|c|c|c|}
\hline \multirow[b]{2}{*}{ Year } & \multirow[b]{2}{*}{$\begin{array}{c}\text { Quantity } \\
\text { (short tons) }\end{array}$} & \multirow[b]{2}{*}{ Value } & \multicolumn{2}{|c|}{ Average for two year period } \\
\hline & & & Value & $\begin{array}{c}\text { Percent of } \\
\text { total a }\end{array}$ \\
\hline $\begin{array}{l}1895 \\
1896 \\
1897 \\
1898 \\
1899 \\
1900 \\
1901 \\
1902 \\
1903 \\
1904 \\
1905 \\
1906 \\
1907 \\
1908 \\
1909 \\
1910 \\
1911 \\
1912 \\
1913 \\
1914 \\
1915 \\
1916 \\
1917 \\
1918 \\
1919 \\
1920 \\
1921 \\
1922 \\
1923 \\
1924 \\
1925 \\
1926 \\
1927 \\
1928 \\
1929 \\
1930 \\
1931 \\
1932 \\
1933 \\
1934 \\
1935 \\
1936 \\
1937 \\
1938\end{array}$ & $\begin{array}{r}709,956 \\
451,840 \\
519,030 \\
620,565 \\
423,270 \\
627,443 \\
611,866 \\
610,408 \\
808,288 \\
944,371 \\
1,278,056 \\
1,666,270 \\
1,625,000 \\
1,814,291 \\
1,271,710 \\
1,591,235 \\
1,050,190 \\
2,276,440 \\
1,840,080 \\
4,003,550 \\
4,294,310 \\
3,369,570\end{array}$ & $\begin{array}{r}\$ 455,076 \\
422,388 \\
587,144 \\
563,586 \\
809,924 \\
604,886 \\
796,852 \\
673,361 \\
597,965 \\
542,170 \\
533,509 \\
577,782 \\
648,135 \\
569,775 \\
609,922 \\
639,831 \\
817,121 \\
998,236 \\
854,814 \\
594,681 \\
577,295 \\
610,534 \\
580,750 \\
444,800 \\
567,356 \\
840,544 \\
563,427 \\
719,203 \\
775,134 \\
739,632 \\
904,669 \\
952,141 \\
1,267,033 \\
1,742,252 \\
1,560,066 \\
1,850,832 \\
1,210,705 \\
1,389,465 \\
920,532 \\
1,934,364 \\
1,645,937 \\
3,397,356 \\
4,276,891 \\
3,782,480\end{array}$ & $\begin{array}{r}\$ 438,732 \\
575,365 \\
707,405 \\
735,106 \\
570,067 \\
555,645 \\
608,955 \\
624,876 \\
907,678 \\
724,747 \\
593,914 \\
512,775 \\
703,950 \\
641,315 \\
757,383 \\
928,405 \\
1,504,642 \\
1,705,449 \\
1,300,085 \\
1,427,448 \\
2,521,646 \\
4,029,685\end{array}$ & $\begin{array}{r}6 \\
7 \\
7 \\
6 \\
4 \\
4 \\
3 \\
3 \\
4 \\
3 \\
2 \\
1 \\
1 \\
2 \\
2 \\
2 \\
4 \\
5 \\
6 \\
10 \\
5\end{array}$ \\
\hline
\end{tabular}

a Percent of total value of all minerals produced in Iowa for the two year period designated.

minerals in Iowa (Plate VIII and Table VI). The outstanding features of the industry from 1894 to 1921 are the above-average productions in 1899, 1901-1902,1910-1913 and 1920, and the even tenor of output values for the remainder of the period. It is striking that the world war ${ }^{*}$ and post war conditions which inflated most other mineral productions affected limestone only slightly. In 1922, however, 
a strong upswing started which carried through 1930, interrupted only in 1924 and 1926 by eurtailment in production.

The effects of the depression influenced the limestone industry less than any other mineral commodity, and although the value of limestone production fell off in 1930-1932 it remained well above average and in 1934 exceeded the value of any preceding year with an output totalling $\$ 1,934,364$. After a decline in 1935 the value of production increased greatly in the succeeding years and was far above average from 1936 to 1938 . An output of $4,294,310$ tons valued at $\$ 4,276,891$ in 1937 established a record for limestone production in the state. No production of lime has been reported in Iowa since 1930.

The quantity produced followed the trend of values rather closely. The peak was reached in 1934 when 2,276,440 tons were produced. An indication of the relative advancement of limestone is seen in the fact that in 1918 it represented about 1 per cent of total mineral production in Iowa while in 1933-1934 it represented 8 per cent of the total.

A relatively small production of sandstone is included in the table and columnar diagram.

\section{Sand and Gravel}

The trend of production for sand and gravel (Plate IX and Table VII) was generally upward from the first year data are available (1906) through 1923, although declines over the previous year occurred in 1911, 1913, 1918, and 1921. After a sharp reversal in 1924 an upswing started that culminated in 1930 with a production valued at $\$ 2,599,107$ which exceeded that in any other year in the history of the industry. Large declines occurred in the depression years of 1931 and 1933. In 1933 the value dropped to $\$ 1,165,006$ which was less than for any year after 1918. The industry started a strong upward trend in 1934 which continued without decline through 1938. In 1938, when most other mineral commodities were affected by the recession, the sand and gravel industry reported an output valued at $\$ 2,299,732$, the second largest in the history of production in lowa.

The quantities of sand and gravel produced varied greatly. It was greater than 1,000,000 tons from 1909 to 1927, greater than 2,000,000 tons since 1927 and the maximum of $6,994,286$ tons was marketed in 1938. 


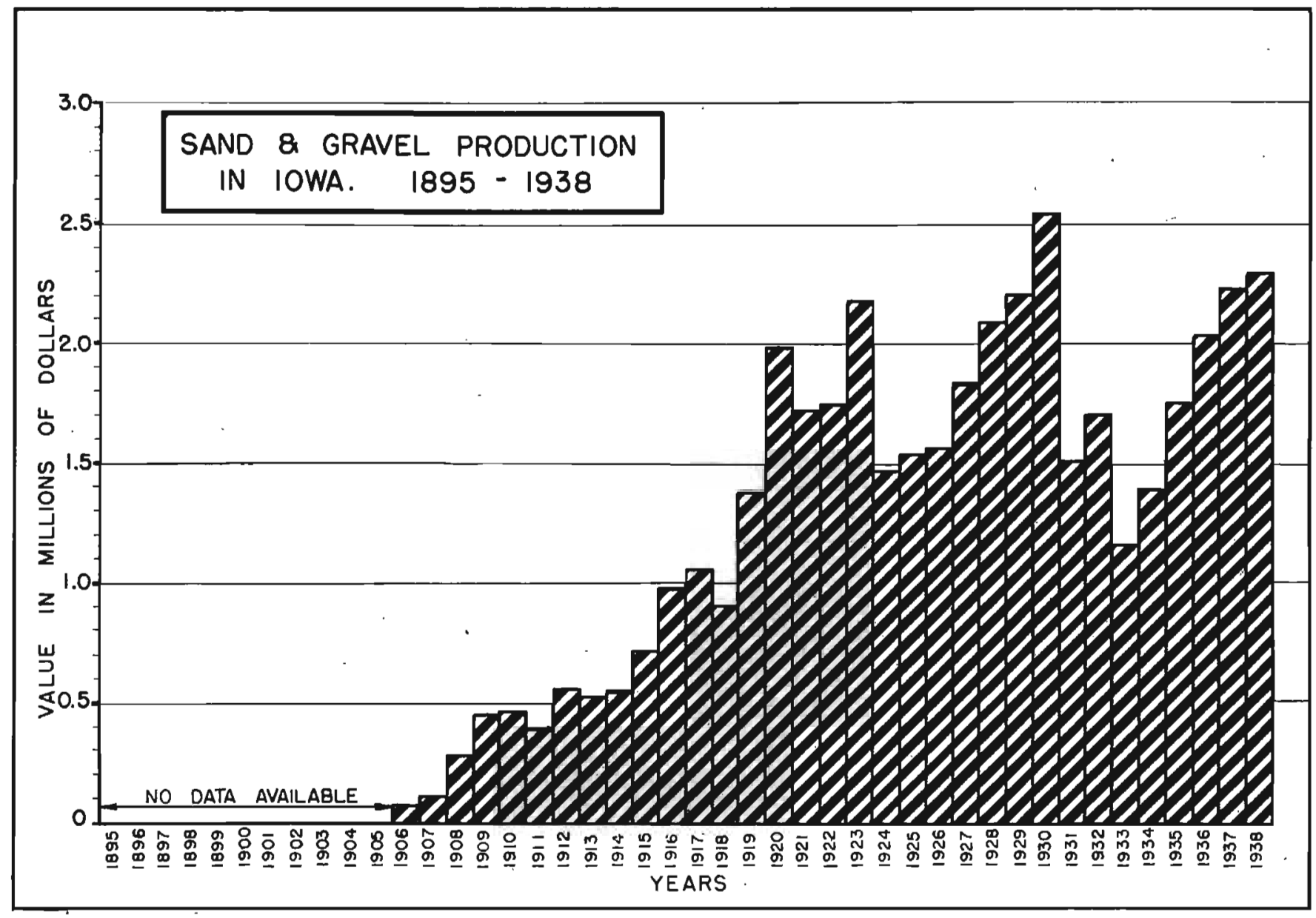

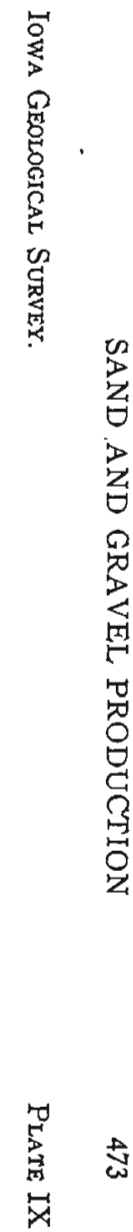


TABLE VII

Sand and Gravel Production in Iowa-1895-1938

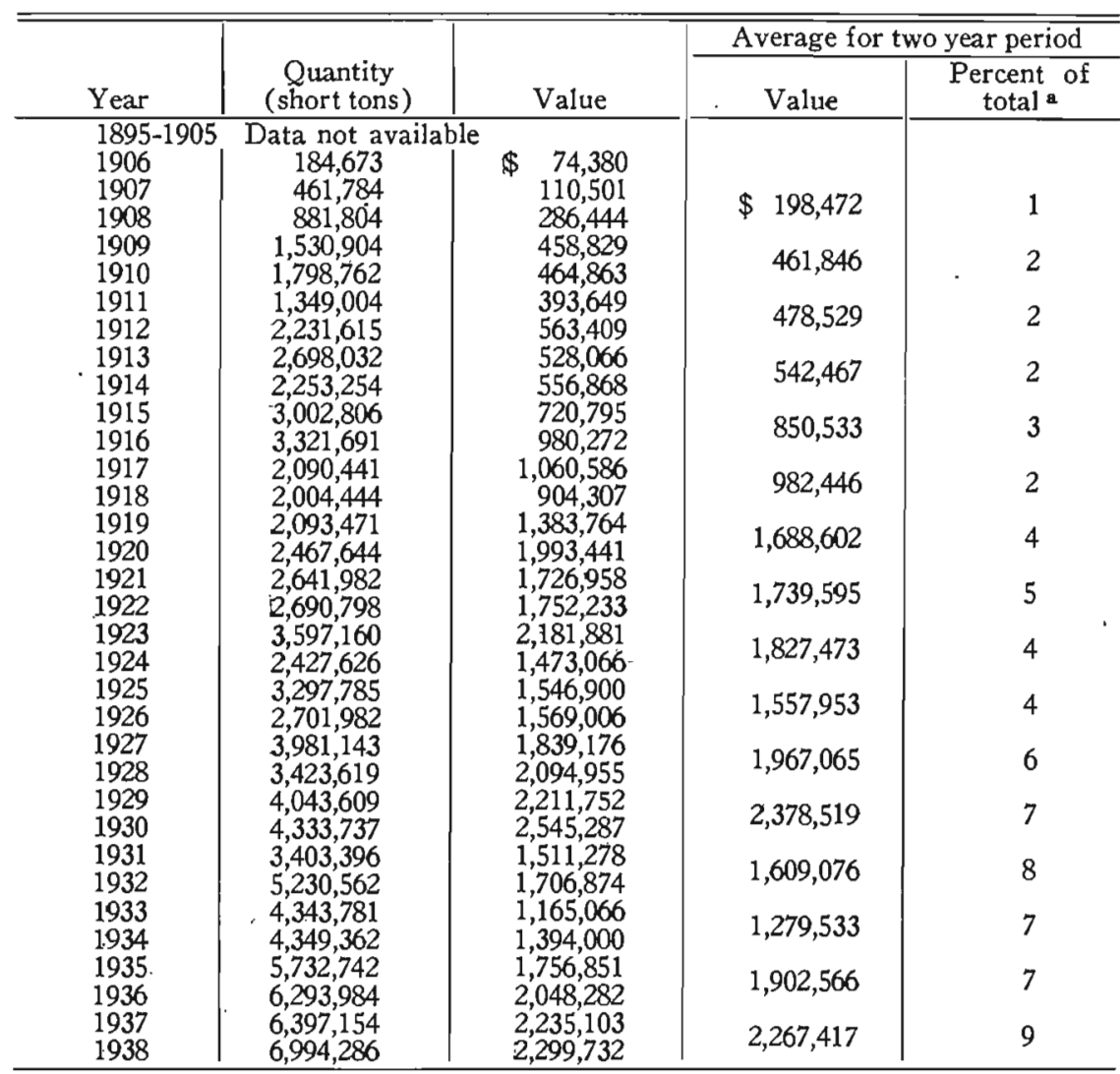

a Percent of total value of all minerals produced in Iowa for the two year period designated.

The average price per ton of sand and gravel was low from 1906 to 1915 , but increased in the ensuing years and maintained a relatively high level until 1932 when it dropped and remained depressed through 1938. 